\title{
Islam dan Etika Pergaulan Hidup Internal Umat
}

\author{
Oleh : Soeroyo
}

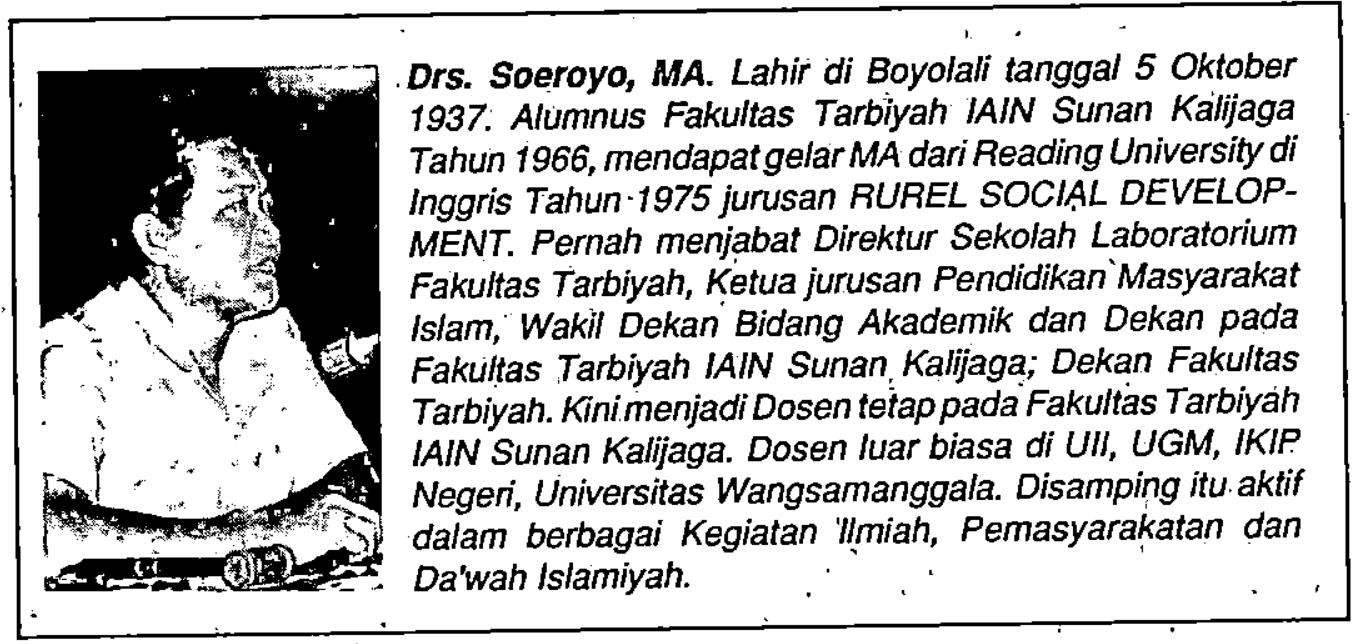

\section{Pendahuluan}

Missi, utama diutusnya Nabi Muhammad s.a.w. di muka bumi ini tidak lain kecuali menjadi rahmat bagi seluruh alam Wa maa arsalnaaka illa rahmatan lil alamin. (Q.S. 21 : 107) Jadi tujuan utamanya menyebarkan rahmat, berarti menyebarkan nilai-nilai kasih sayang. Islam, tidak mengajarkan kebencian dan permusuhan. Kasih sayang itu untuk seantero alam semesta di lingkungan hidup kita masing-masing (lil .'alamin). Jadi AlQur'an menyebut bukan lil mukminin atau lil muslimin saja. Dengan kata lain siapa saja, bahkan orangmunafik atau orang kafir sekalipun akan mendapat rahmat ketika berhubungan dengan umat Islam baik sebagai individu maupun kolektivitas. Begitu juga orang-orang N̦asrani, Hindu,
Budha dan sebagainya seharusnya mendapat rahmat dengan keberadaannya uriat Islam.

Oleh karena itu, tidaklah mengherankan kalau di Indonesia menerapkan konsep kerukunan hidup beragama: "agree in dis agreement" (setuju dalam perbedaan). Ia percaya bahwa agama yang ia peluk itulah agama yang paling baik; dan di antara agama satu dengan lainnya, selain terdapat perbedaan terdapat juga persamaan. Dan berdasarkan pengertian itulah maka saling harga menghargai ditimbulkan antara pemeluk agama yang satu dengan pemeluk agama yang lain.")

1) Prof. Dr. A. Mukti Ali, Kuliah Agama Islam di SESKAU Lembang, Yayasan "Nida" Yogyakarta. 
Konsep kerukunan ini sudah cukup lama berjalandi Indonesia. Setidak-tidaknya pada tahun 1972 ketika Pak Mukti Ali menjabat Menteri Agama Republik Indonesia. Dengan dasar pemikiran dan kenyataan bahwa bangsa Indonesia adalah hidupdalam "plural society" masyarakat serba ganda, ganda kepercayaannya, kebudayaannya, aspirasi politịknya, agamanya dan sebagainya. Sementara itu pembangunan di Indonesia mustahil dapat terlaksana dalam masyarakat yang tidak rukun dalam arti kacau. Kenukunan hidup masyarakat merupakan pra kondisi bagi pembangunan.

Apa yang dapat disaksikan, bahwa dengan konsep itu, pemerintah cukup stabil dan pembangunan dapat berjalan dengan baik.

Kerukunan hidup antarumat beragama telah berjalan dengan , mengagumkan bagi bangsa-bangsa lain yang melihat on the spot pergaulan hidup antarumat beragama. Antar umat beragama saling tenggang menenggang rasa dan lapang dada (tasamuh atau toleransi). Tentu saja ini bukan suatu hal yang mudah.

Ironisnya, ketika kita berhasil menciptakankonsepetika pergaulan "agree in dis agreement" dan terlaksana dengan baik di antara umat beragama di Indonesia, kita justru belum mempunyai etika pergaulan hidup intern umat Islam ketika kita berbedapendapat. (Kasus Islam jama'ah dan yang terakhir Darul Árqam serta hubungan NU - Muhammadiyah dulu).

Yang terjadi biasanya berusaha saling mengecilkan satu sama lain yang berujung saling (ingin) menghancurkan satu sama lain.

Inilah barangkali yang perlu kita cari jalan keluarnya, ketika kita berbeda pendapat.
Etika pergaulan hidupyang bagaimana yang seharusnya kita lakukan. Etika kenukunan hidup bagaimana yang Islami itu ?

\section{Pokok-pokok Ajaran Islam}

Secara klasik dengan mengacu pada Hadits Rasulullah, pokok ajaran Islam itu ada 3 yaitu Iman, Islam dan Ihsan. Iman berkaitan dengan akidah, keyakinan terhadap hal-hal yang ghoib sebagaimana diajarkan dalam kitab suci Al-Qur'an. (Alladziina yu'minuuna bil ghoibi). Iman yang tertinggi adalah : Laa ilaha illallah, sedang iman yang paling rendah tingkatannya adalah menyingkirkan duri (batu) di tengah jalan. Kemudian ajaran pokok Imandari Rosulullah diformulasikan dalam sistem rukun iman yang terdiri dari 6 pilar itu.

Ajaran pokok yang kedua adalah "Islam" yang merupakan ekspresi atau pernyataan iman seseorang. Islam merupakan dimensi pengamalan dari iman. Adalah omong kosong apabila seseorang mengatakan dirinya beriman, akan tetapi tidak mengamalkan apa yang diharapkan dari yang diimani. Sebaliknya amal seseorang baru terbilang di muka Allah apabila dilandasi oleh Iman yang benar. (Inilah makna tebaran ayat-ayat dalam AlQur'an yang menyatakan : "Kecuali orangorang yang beriman dan beramal sholeh Illalladziina amanu wa'amilu sholihaat). Jadi Islam lebih merupakan dimensi horizontal (hablun minannaas)

Selanjutnya sistem Islam, diformulasikan ke dalam 5 pilar rukun Islam dalam bentuk ibadah kepada Tuhan dan berbuat kebajikan (menyebarnilai-nilai kasih) kepada sesama manusia. Adapun Ihsan diartikan secara khas oleh Rosulullah ketika beliau 
menjawab pertanyaan malaikat Jibril sebagai berikut :

Adapun Ihsan adalah:

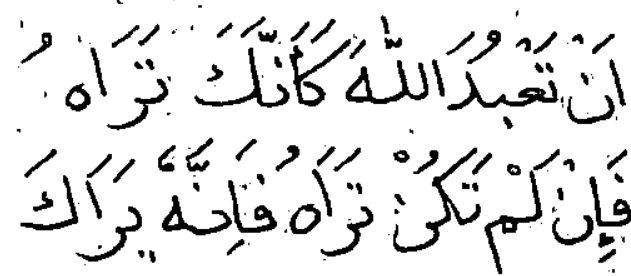

Artinya :

Hendaklah ketika kamu beribadah kepada Allah, seakan-akan kamu melihat-Nya (berdialog denganNya). Apabila kamu sulit melakukannya maka hendaklah kamu merasa bahwa sesungguhnya Allah sêlalu melihatmu.

Jadi Ihsan 'pada hakekatnya merupakan derajat seseorang yang selalu merasa dirinya dilihat oleh dzat yang Ghaib. yang kepadaNya manusia semua bergantung dan memohon pertolongan.

Ihsan sebenarnya merùpakan manifestasi dari keimanan seseorang yang akan terwujud pada perilaku, tindakan amal, serta akhlak yang luhur.

Inilah sebabnya Ihsan dikatagorikan sebagai dimensi akhlak tasawuf. Sedangkan Islam adalah dimensi syari'ah atau ibadah. Semantara Iman merupkan dimensi aqidah.

Pemahaman pokok ajaran Islam tersebut sungguh sangat mendasar dan penting. Dalam kaitannya dengan etika. pergaulan hidup intern umat Islam, pemahaman pokok ajaran Islam tersebut sungguh sangat mendasar dan penting. Dalam kaitannya dengan etika pergaulan hidup intemumat Islam, pemahaman pokok ajaran Islam dapat diringkas menjadi pokok ajaran saja yaitu : a. Percaya kepada Tuhan Yang Maha Esa (Tauhid).

(Laa ilaha illallah ).

b. Berusahä untuk menyempurnakan sifat kehambaannya. (ubudiyah )'.

Jadi setelah dada diisi dengan kalimah tauhid ( tauhid rububiyah ), maka selanjutnya berusaha untuk menjadi hamba Allah yang baik, dengan melakukan ajaranajaranNya dengan sukárela dan melaksanakàn perintah-perintah-Nya dengan tulus dan khidmat itulah inti ajaran Islam.

Jelasnya, setelah dada diisi dengan iman (tak ada' sesernbahan lain kecuali Allah), maka semua orang di hadapan Allah adalah sama derajatnya. Yang. membedakan selanjutnya adalah apakah seseorang itu berusaha untuk menyempumakan dirinya apakah tidak. Adakah ia berusaha bahwa hari ini lebih baik daripada kemarin atau tidak. Apakah ada usaha bahwa hari esok lebih baik dari yang sekarang.

Jadi usaha seseorang yang selalu berusaha menyempumakan diri sebagai hamba Allah yaríg baik dan sempuma (insan kamil) mempunyai nilai etis yang tinggi di sisi Allah. Dan itulah makna firman. Allah: Inna akramakum indallahi atqaakum.

Artinya :

Sesungguhnya orang yang paling mulia derajatnya di sisi Allah adalah orang yang paling taqwa di antaramu. 
Kerukunan Hidup Umat dan Risalah Islamiyah

Apayang dimaksud dengan "Risalah Islamiyah" adalah alasan pokok atau tujuan. utama apa diutusnya Muhammad Rosulullah ke muka bumi ini. Ada dua ungkapan yangmemberi penegasan tentang hal ini.

Pertama : penegasan dari Al-Qur'an sendiri

Kedua ! penegasan dari Nabi Muhammad s.a.w. dalam Haditsnya.

Di dalam Al-Qur'an ditegaskan bahwa tujuan utama atau misssi utamanya adalah rahmatan lil 'alamin.

Dalam surat Al-Ambiya 107, Allah s.w.t. berfiman :

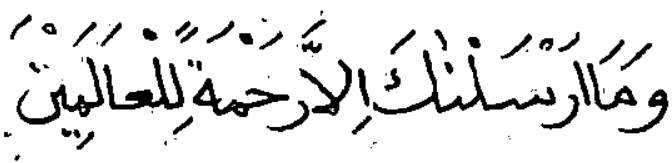

Artinya:

Dan tidaklah Aku mengutus kepadamu (Muhammad) kecuali untukmenjadi rahmat bagi seluruh alam semesta.

Sedangkanungkapankeduaditegaskanoleh pernyataan nabi Muhammad s.a.w. sendiri bahwa beliau diutus hanyalah untuk menyempurnakan budi luhur manusia. Hadits Rosulullah :

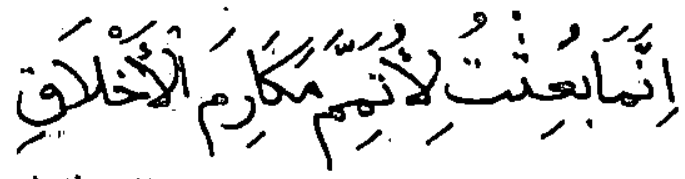

Artinya :

- Sesungguhnya aku diutus tidak lain untuk menyempurnakan ahlak yang mulia.

Ungkapan pertama mengandurig penekanan bahwa Nabi Muhammad yang diutus ke dunia untuk membawa agama
Islam kepada umat manusia tidak mempunyai tujuan lain kecuali menyebarkan nilài-nilai kasih sayang.

Yangkeduamengandung penekanan bahwa seluruh usaha dan perjuangan Nabi Múhammad ditujukan hanya untuk dan dalam rangka pembinaan akhlak manusia. Ini berarti sasaran Islam adalah membangun manusia sebagai individu dan masyarakat yang bermoral dan berakhlak: Dari penegasan itu, kita dapat menyimpulkan bahwa ada dua kata kunci yang menjadi tujuan utama "Risalah Islamiyah" yaitu "rahmat" (kasih sayang) dan "ahlakul karimah".

Dengan ungkapan yang lebih jelas barangkali dapat disimpulkan bahwa pada hakekatnya "Risalah Islamiyah tidak lain dari membangun suatu kehidupan yang diikat oleh rasa kasih sayạng berlandaskan nilai-nilai yang luhur, suatu masyarakat yang seperti diisyaratkan oleh salam Islam yaitu: "Assalaamu 'alaikum warahmatullahi wa barakatuh" penuh rasa damai, sejuk, kasih dan sayang serta mendapat ridha dan berkah Allah s.w.t.

Kalau intisari dari "Risalah Islamiyah" demikian, maka kenukunan antar umat beragama yang dilaksanakan dalam etika pergaulan hidup bukan suatu hal yang asing tetapi justru merupakan missi pokok. Mengapa demikian ? Karena kasih sayang itu haruslah disebarkan di seluruh alam di sekitar kita. Eksistensi umat Islam dimanapun berada dan kapanpun haruslah menjadi rahmat. Keberadaan umat Islam baik secara individu maupun kolektif harus dirasakan sebagai rahmat bagi umat beragama lain (Nasrani, Hindu dan Budha). Bahkan orang munafik, kafir sekalipun harus mendapat rahmat dengan keberadaan 
umat Islam tersebut.

Apabila etika pergaulan antar umat beragama dapat berjalan begitu indah dan luhur,maka seharusnyalah pergaulan intem umat beragama (sekalipun ada perbedaan yang fundamental) haruslah lebih dari itu. Hal ini sebagaimana ditegaskan oleh Nabi Muhammad s.a.w. dalam Hadits sebagai berikut :

Artinya :

"Persaudaraan antara seorang Muslim yang satu dengan yang lainnya laksana bangunan tembok yang kokoh saling menguatkan satu sama lain".

Nabilalumerajahkan jari-jemarinya sebagai gambaran persaudaraan Islam tersebut.

Adalah sangatmemprihatinkan, apabilakita melihat etika pergaulan hidup atau kerukunanhidup intem ummat Islam justru saling melecehkan, saling mengecilkan, bahkan saling membunuh dan sebagainya. Padahal Nabi Muhammad menegaskan :

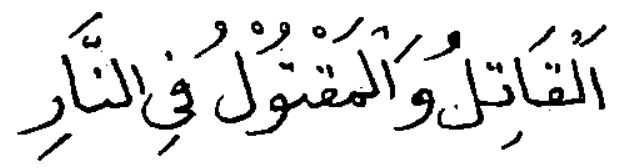

Artinya :

Yang membunuh dan yang dibunuh semuanya masuk neraka.

Konsep Etika Pergaulan dalam Keruḳunan Hidup beragama

Para ahli fikir telah mencoba untuk mencarikonsepkerukunanhidupberagama. Rukun dalam kehidupan agama dapat tercipta apabila tiap-tiap orang itu saling tenggang menenggang rasa dan berlapang dada. Tentu saja ini bukanilah suatu hal yang mudah. Setidak-tidaknya ada empat. pola pemikiran telah diajukan orang untuk mendapatkan kerukunan dalam kehidupan antar umat beragama.

a. Pola sinkretisme.

- Pola ini didasarkan pada pemikiran bahwa pada hakekatnya semua agama itu adalah sama. Mereka hendak mencoba mencampur baurkan ajaran agama-agama itu menjadi satu:"

Agama yang berbeda-beda itu hanyalah berbeda dalam faktor historis dan geografi, bukan dalam hakekat. Tidak ada agama yang mengandung sesuatu yangmutlak. Semuaagamaadalah relatif dan instrumentalis danmaknyanya ialah sebagai alat untuk mencapai tujuan. Dalam segi theologi,maka yangmenjadi dasar sinkretismeialah suatu pandangan hidup yang tidak melihat adanya "garis batas" antara Tuhan dengan diciptakanNya, antara khaliq dengan makhlukNya. Aliran ini juga dinamakan Pantheisme, Universalisme atau Pan kosmisme dan sebagainya. Maksudnya adalah bahwa semua (pan) adalah Tuhan (theos).

Faham pantheistis ini sebenamya juga terdapat dalam kalangan tasawuf Islam.

b. Pola synthese, ialah usaha untuk menciptakan suatu agama baru yang elemen-elemennya diambilkan dari pelbagai agama, agar supaya dengan demikian tiap-tiap pemeluk ágama merasa bahwa sebagian dari ajaran agamanya telah diambil dalam agama synthesis. Dengan cara ini orang menduga bahwa kehidupan agama akan rukun.

c. Pola penggantian, adalah pola yang mengakui bahwa agamanya sendiri itulah yang benar, sedang agama-agama lain adalah salah; dán berusaha agar supaya orang-orang yang lain agama itu 
masuk dalam agamanya. Ia tidak rela, bahwa orang lain itu mempunyai agama dan kepercayaan yang berlainan dengan agamanya. Agama yang hidup itu harus diganti dengan agama yang ia peluk, dan dengan ini ia menduga bahwa kerukunan hidup beragama baru dapat tercipta.

d. Pola agree in dis agreement ialah suatu polapemikiran yangmenyatakan bahwa seorang pemeluk agama haruslah percaya bahwa agama yang ia peluk adalah agama yang paling benar dan paling baik. Namun demikian ia juga mengakui bahwa selain terdapat perbedaan juga terdapat persamaannya. Berdasarkan persamaan ajaran itulah mereka setuju untuk hidup berdampingan dalam kehidupan sosial. Dengan meyakini bahwa agamanya adalah yang paling benar, timbullah suatu dorongan untuk berusaha supaya perilakunya sesuai dengan ucapan batinnya, sesuai dengan ajaran agamanya yang baik itu.

Sistim Nilai (Value system) dan Potensi Berbeda Pendapat.

Suatu ajaran atau doktrin, juga kitab suci pada hakekatnya merupakan sistem nilai. Ini terdiri dari kumpulannonma-norma atau aturan-aturan yang normatif.

Norma-norma itu harus diaplikasikan atau ditrapkan dalam kehidupan sosial yang bermacam-macam tingkat kecerdasan dan budayänya.

Oleh karena itu dalam usahanya untuk menerapkan norma-norma ke dalam kehidupan sosial atau kehidupan masyarakat harus melalui proses interpretasi. Setiap interpretasi selalu dipengaruhi oleh subjek (siapa) yang memberikan interpretasi. Oleh karena itu setiap interpretasi pasti subjektif yang berpotensi untuk berbeda pendapat.

Begitu juga kitab Suci Al-Quran sebagai kumpulan sistem nilai yang nomatif, ketika akan diaplikasikan dalam kehidupan sosial memerlukan interpretasi. Seperti diketahui ayat Al-Qur'an ada yang muhkamah dan ada yang muta-syabihat. Untuk yang kedua memerlukan penafsiran ketika akan diterapkan dalam kehidupan sosial.

Setiap penafsiran pastilah subjektif. Itulah sebabnya dalam bidang hukum dunia Islam mengenal madzab Hanafi, Maliki, Hambali dan Syafi'i. Kita tidak usah heran kalau melihat orang yang melakukan sholat di Masjidil Haram bervariasi dalam penampilannya. Ada yang mendekapkan kedua tangannya di dada (madzab Syafi'i), sementara yang lain melepaskan tangan lurus-lurus (madzab Maliki), setelah takbiratul ihram. Tentunya baik madzab Syafi'i maupun madzab Maliki sama-sama mengacu pada Hadits :

Artinya:

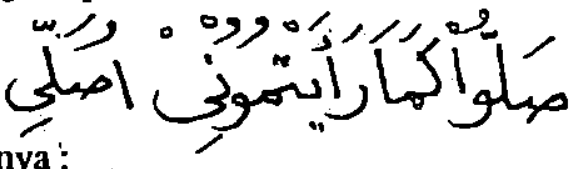

sholatlah kamu sekalian, sebagaiman aku melakukan sholat.

Jadi ketika kita akan mengaplikasikan ayatayat Al-Quran dalam kehidupan sosial, maka di sana kita harus melalui proses interpretasi. Dan ketika orang menginterpretasikan ayat tersebut pastilah latar belakang seseorang tadi mempengaruhi penafsirannya. Penafsiran seseorang pastilah subjektif.

Jadilah kita mengenal Isiam Ahlu Sunnah wal Jama'ah, Islam Syi'ah, Islam 
madzab Syafi'i, Maliki, Hambali dan Hanafi dan sebagainya. Di Indonesia kita kenal Islam Muhammadiyah, Islam NUU, Isläm Jama'ah, Islam' Darul 'Arqam dan sebagainya. Dua yang terakhir ini telah dinyatakan dilarang di Indonesia.

Jadi meskipun kita gencar mengatakan kembali kepada AI-Qur'an dan Sunnah, maka ketika kita mengembalikan persoalan yang muncul pada $\mathrm{Al}-\mathrm{Qur}$ 'an dan Hadits, di sana terdapat potensi untuk berbeda pendapat dalam menafsirkan ayatayat tersebut.

Dalam hubungannya dengan'NUdan' Muhammadiyah, mereka sama-sama kembali kepada Al-Qur'an dan Sunnah, tetapi dalam penampilan, performance dalam mengambil hukum sering kali berbeda.

Pada hakekatnya mereka hanya berbeda metode dalam menentukan hukum. Di lingkungan Muhammadiyah kalau *menjumpai sesuảtu masalah pertama-tama dicarikan naskahnya dalam Al-Qur'an, kemudian kepada Hadits, dan selanjutnya dilacak pada pendapat ijma' para Ulama. Sementaraitu dikalangan Ulama Nahdhatul: Ulama, kalau menjumpai suatu persoalan langsung di lacak dari pendapat Ulama terdahulu (ijma'), baru -kemudián dicari dalam Al-Qur'an dan Hadits. Jadi hanya berbeda dalam metode. Mengapa seringkali berbeda pendapat, hal ini disebabkan karena seringkali di kalangan Ulama NU hanya berhenti pada pendapat ijma' Ulama,'tidak meneruskan kepada Al-Qur'andan Sunnah. Sementara di kalangan Ulama Muhammadiyah setelah dicari ayat-ayat di dalam Al-Qur'an dan Hadits, tidak terus melacak atau mencocokkan dengan pendapat padaijma' Ulama yang terdahulu.

\section{Selanjutnya what next?}

Pertama : Adanya perbedaan pendapat nampaknya memang merupakan hal yang tak mungkin dihindari. Sebab ketika kita akan mengaplikasikan sistem nilai dalam bentuknorma-noma pada Al=Qur'an, harus melalui proses interpretasi. Di sana pasti akan terjadi perbedaan pendapat. Ahmad Wahib pernah menyatakan :Islam saya ini' mungkin Islamnya Natsir, atau Islamnya Hamka dan sebagainya. Sikap yang terbaik adalah sikap krasan berbeda pendapat. Artinya tanpa melecehkan, atau mengecilkan pendapat orang lain. Kita hidup dalam pergaulan sosial secara ni'mat dan nyaman. Ketikakita menyangka bahwa pendapat kita adalah yang paling benar, janganlah rongga dada ini dipenuhi dengan dugaan kebenaran tersebut. Seyogyanya ada ruang vacuum meskipun sedikit untuk menerima pendapat' orang lain yang mungkinlebih benar. Etika pergaulan hịdup demikian patut dibudayakan di kalangan intern umat Islam untuk menghindari benturan-benturan keras yang selama ini dapat disaksikan bersama.

Kedua $\quad$ Apabila kita mengacu pada pokok-pokok ajaran Islam, dimana Tauhid (Laa ilaha illallah) menjadi pokok ajaran yang utama; maka persoalan-persoalan ummat dapatlah digambarkan sebagai piramida yang berpuncak pada Tauhid. Di bagian bawah dari piramida yang tumpul terdapat persoalan-persoalan 'dan perbedaan-perbedaan pendảpat' yang banyak dan beraneka ragam. Akan tetapi semuanya hanyalah merupakan cabangcabang saja, bahkan kebanyakan hanyalah perbedaan ' ranting-ranting, bukan perbedaan pokok.

Semua perbedaan itu dapat 


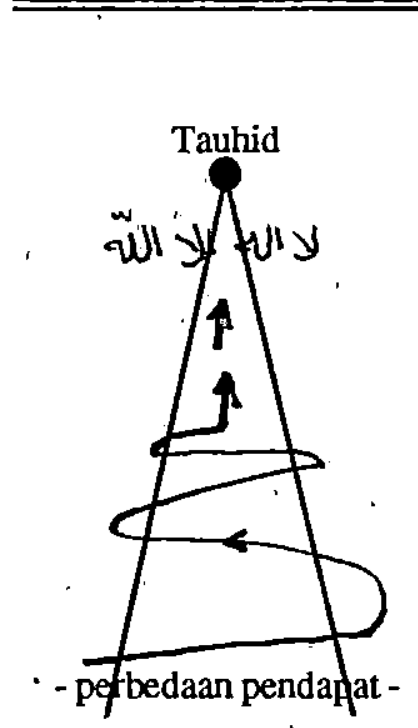

ditarik dapat diterima, karena tiap-tiap ajaran, m e n u ju $\mathrm{kepad} a$ pun c a k piramida yaitu tauhid (Laa ilaha illa1lah). Kita harus mengakui d a $\mathbf{n}$ menyadari b a $h$ w a disamping perbedaan $\begin{array}{llll}\mathbf{y} & \mathbf{a} & \mathbf{n} & \mathbf{g}\end{array}$ terdapat di antara satu aliran atau satu madzab dengan aliran atau madzab lain, masih banyak persamaan-persamaan-nya. Dan puncak dari persamaan itu adalah Laa ilaha illallah. Atas dasar itu saling bantu membantu, hormat menghormati dan harga menghargai ditegakkan dan ditumbuhkan.' Dengan dasar inilah, ukhuwah Islamiyah dalam pergaulan hidup intern ummat beragama dapat diciptakan. Dan itu proses menuju pada seruan Muadzin yang telah didengungkan semenjak 15 abad yang lalu: "Hayya 'alal falaah" (marilah menuju kemenangan). Kemenangan di sini menurut hemat saya lebih cenderung pada kemenangan duniawi. Hal ini disebabkan kárena kemenanganukhrowi sudah hampir dapat dipastikan menjadi bagian dari apa yang dijanjikan Allah kepada ummat Islam sebagai ummat Muhammad.

Ketiga : Apabila kita méngacu pada pola-pola kerukunan hidup beragama di atas, kita bisa memberikan analisa sebagai berikut : Pola pertama dan kedua yaitu pola sikapsinkretisme dan sinthese rasanya tidak belakang sejarahnya sendiri-sendiri yang tidak begitu mudahuntuk diputuskan. Tiaptiap aliran atau madzab terikat kepada hukum-hukum sejarah masing-masing. Adapun pola pemikiran atau pola sikap ketiga dengan jalan "peng-gantian" juga tidak Islami, tidak dapat diterima. Jalan pengganti-an akan menimbulkan kerugian dan kehancuran. Akan terjadi perang saudara yang berke-panjangan.

(Syi'ah kontra Ahlu Sunah Wal Jama'ah, merupakan bukti sejarah yang akhirnya berkepanjangan pada perang antara Iran dan Iraq).

Barangkali pola pemikiran dan pola sikap "setuju dalam perbedaan", krasan berbeda pendapat inilah jalan yang paling baik diambil dalam rangka mewujudkan integrasi ummat Islam dalam menciptakan Ukhuwah Islamiyah. (Baca:Prof. A. Mukti Ali = kuliah agama Islam di SESKAU)

Setiap jama'ah atau aliran, syah-syah saja untuk menganggap ajarannya adalah yang paling baik dan paling benar. Adalah suatu kebodohan apabila seseorang tidak meyakini ajaran alirannya sebagai ajaran yang paling baik dan paling benar. Tetapi konsekwensinya adalah, dengan keyakinan bahwa alirannya adalah yang paling benar timbul dorongan atau gairah untuk berusaha agar supaya tinđak lakunýa (perilakunya) sesuai dengan ajaran yang diyakini paling benar tadi. Ajarannya haruslah merupakan "an acute fever" demam yang membara dalam dadanya, barulah ajaran aliran tersebut ada gunanya. Apakah pola "setuju dalam perbedaan" ini sesuai dengan perintah Allah : lakum diinukum waliyadiin ?

Wallahu a'lam bishshawab. 